Muséologies

Les cahiers d'études supérieures

muséologies

\title{
Art/Action: Dialoguing with the Québec Spring Movement
}

\section{Tina Carlisi}

Volume 7, numéro 1, 2014

Le dialogue dans les musées d'art contemporain

URI : https://id.erudit.org/iderudit/1026646ar

DOI : https://doi.org/10.7202/1026646ar

Aller au sommaire du numéro

Éditeur(s)

Association Québécoise de Promotion des Recherches Étudiantes en

Muséologie (AQPREM)

\section{ISSN}

1718-5181 (imprimé)

1929-7815 (numérique)

Découvrir la revue

Citer cet article

Carlisi, T. (2014). Art/Action: Dialoguing with the Québec Spring Movement.

Muséologies, 7(1), 33-52. https://doi.org/10.7202/1026646ar

Tous droits réservés (C Association Québécoise de Promotion des Recherches Étudiantes en Muséologie (AQPREM), 2014
Ce document est protégé par la loi sur le droit d'auteur. L'utilisation des services d'Érudit (y compris la reproduction) est assujettie à sa politique d'utilisation que vous pouvez consulter en ligne.

https://apropos.erudit.org/fr/usagers/politique-dutilisation/ 
Article un

\section{Art/Action: Dialoguing with the Québec Spring Movement}

Tina Carlisi 
Tina Carlisi is an artist whose work explores the potential of print as a socially engaged art and design practice. She often investigates the relationship between individual and collective expression of ideas and ideals with text and image emerging as central components. Carlisi holds a B.F.A. and a Graduate Certificate in Design, an M.A. in Art Education, and recently started her doctoral studies in the Individualized Program (Fine Arts) at Concordia University.

Carlisi's practice-based Master's thesis explored how art and design were used as part of the 2012 student movement in Québec and investigated its relationship to experimental post-secondary art/design pedagogy. The artistic components of her research were shown in a solo exhibition at Nowhere Gallery in Montréal in May 2013. Prior to graduate studies, Carlisi worked as a professional designer in an interior architecture firm in Montréal. She currently works in various cultural fields that include contemporary art galleries and teaching in design. tinacarlisi@hotmail.com 


\section{The Québec Spring}

During the Québec Spring, art and design were used to bring discourses surrounding the movement into public view, to express viewpoints, and to mark the student movement. The adopted symbol, a red square, which was first worn as part of the student movement in $2005^{1}$, was a collective effort to visually communicate support for this cause. For over seven months in 2012, students from more than a dozen cégeps (colleges) and universities throughout Québec went on strike as a protest against the then provincial government's budget plans to raise university tuition. ${ }^{2}$ All throughout the province, and more specifically in Montréal, students and non-students alike participated in mass demonstrations, casserole banging $^{3}$, and other forms of manifestation on the street. At the center of this activism, art and design expressed the concerns of this movement throughout the city, ranging from posters and installations to performances and yarn bombing.

The studio intensive Recto/Verso:

Manifestation/Demonstration presented at Concordia University's Faculty of Fine Arts (FOFA) Gallery in the summer of 2012 considered this period of intensified activism on the streets as a starting point to investigate its implications regarding manifestation and demonstration. This article will present the studio intensive and will discuss the dialogic aspects of the programming. Conceptualized as both a residency and exhibition, Manifestation/ Demonstration was developed in response to the then ongoing student strike. In effect, documentation of the processes and dissemination of daily events and participatory activities were adopted as active spaces for creative expression.

1 Before becoming a symbol of the student struggle, the carré rouge (red square) was used for the fight against social assistance reform in 2004. In 2005, students in the Sociology Department at Université du Québec à Montréal (UQAM) decided that it would become the symbol of their movement. They also considered their struggle to be against poverty. See: Radio Canada. Michel Chartrand appuie les étudiants. <www. radiocanada.ca> (retrieved on January 15, 2013).

2 The planned increase for tuition was from $\$ 2,168$ to $\$ 3,793$ between 2012 and 2017. This represents a hike of $\$ 325$ annually and an increase of $75 \%$ in five years.

\section{Manifest/Demonstrate}

The FOFA Gallery is an exhibition and research space that reflects the creative diversity, activities, and interest of the Faculty of Fine Arts at Concordia University ${ }^{4}$. Their onemonth summer studio intensive, Recto/Verso, inverts the gallery into a site of production and exchange. This studio intensive was in its second year in 2012, when artists were invited to use the gallery as a work site and as a location to collaboratively connect with other participating artists, gallery programmers and its publics, through a series of artistic gestures. The programming involved a continually changing visual environment in the gallery, silk-screening workshops, participatory activities, and a series of outdoor screenings of films produced by the National Film Board of Canada (NFB).

I was part of the Recto/Verso programming team, in collaboration with two other Fine Arts students at Concordia University, Joshua Fourney and Katerina Lagassé. The three members came from diverse artistic and academic backgrounds and all were inspired by and interested in how social movements can be conceived as ephemeral spaces for creation. Atypical from the exhibition programming at the FOFA Gallery throughout the fall and winter, which is determined a year in advance, the programming for Recto/Verso: Manifestation/ Demonstration was a timely process. In a short period before the summer studio intensive began, the programming team laid out a framework for Manifestation/Demonstration, which provided both focus and flexibility for the participating artists and their publics. In conversation with the FOFA Gallery Director, jake moore, the three programming members

3 Casserole banging is a form of popular protest in South America - referred to in Spanish as cacerolazo - which originated in Chile. In 1971, women from the middle upperclass started this form of protest against the socialist government led by the Salvador Allende. Contrary to its roots, pot-banging has since been used to support causes related to socialist ideas. See: KUMARASWAMI, Par \& Niamh THORNTON. Revolucionarias: Conflict and gender in Latin American narratives by women. Bern, Switzerland: Peter Lang, 2007, p.118.

4 FOFA Gallery. Submissions. <www.fofagallery.concordia. ca> (retrieved January, 2013). 
decided to name their team the Recto/Verso Collective. This reflected the group's dynamics, which involved collaboratively working on various tasks from film programming, writing, documenting, designing printed matter and online communications, as well as their direct collaboration with participating artists. Collectivity also deeply reflected the spirit of the student movement.

In response to the Québec Spring, the Recto/ Verso Collective considered the plurality of voices that occupied the movement, and sought to bring communities within and outside of the university to participate in Manifestation/ Demonstration. The Recto/Verso Collective invited École de la Montagne Rouge, an initiative created by young artists who are mainly from the bachelor of graphic design program at Université du Québec à Montréal (UQÀM) ${ }^{5}$, to be the main participants in the studio intensive. Additionally, they invited a diverse group of women, who are all originally from Mexico, to participate in the studio intensive closing event.

\section{École de la Montagne Rouge}

École de la Montagne Rouge was founded on the first day of the student strike and retired when striking students re-entered university after the provincial election, nearly eight months later. The group was actively committed to offering a considered aesthetic approach to the movement as a creative method for helping the Québec Spring make its mark ${ }^{6}$. Inspired by the former Black Mountain College (an experimental art college in North Carolina, active from 1933 through 1957, that was based on John Dewey's philosophy of education ${ }^{7}$ ) as well as by the activities of Atelier Populaire (a university print studio occupied by fine arts students at École nationale supérieure des Beaux-Arts in Paris during May 68 8 ), École de la Montagne Rouge created numerous silkscreen posters, placards and flags for the street

5 École de la Montagne Rouge. Who Are We?

$<$ www.ecolemontagnerouge.com $>$ (retrieved January, 2013).

6 Ibid.

7 HARRIS, Mary Emma. The Arts at Black Mountain College. Cambridge, MA: MIT Press, 1987. manifestations. The collective engaged in collaborations with various artists and organizations, such as Just Seeds Collective, Urbania Magazine, and the National Film Board of Canada (NFB). Manifestation/Demonstration was École de la Montagne Rouge's first residency/exhibition, followed by a residency/ exhibition at the Brooklyn Interference Archive, and a retrospective of their work curated by Frédéric Metz at Centre de Design de l'UQAM in 2012.

The Recto/Verso Collective considered École de la Montagne Rouge's work to be a pivotal contribution to the movement, and the members were enthusiastic about the possibilities that could be stimulated by such a collaboration: one within an open framework between students in support of the movement from English and French universities in Montréal. The collaboration culminated in a one-month residency/exhibition that was constantly evolving. The residency/exhibition was simultaneously participating in the student movement by using the gallery as a site of production for manifestation protest posters. Additionally, the collaborators were engaged in dialogue through exhibition programming that provided access points to multiple socio-political and historical perspectives.

\section{Recto/Verso Film Screening Series}

Each week during the summer studio intensive, a series of short films were presented, courtesy of the National Film Board (NFB), in the gallery's adjacent courtyard and were free to the public. These weekly screenings, programmed by the Recto/Verso Collective, were intended to create a direct connection to the city, as well as to provide a framework for considering questions regarding artists' agency and the convergence between art and activism. As Nato Thompson has noted, "In recent years, there has been a rapidly growing movement of artists who

8 KUGELBERG, Johan and Philippe VERMÈs (Eds.) Beauty Is in the Street: A Visual Record of the May '68 Paris Uprising. London: Four Corners Books, 2010, pp. 9-10. 
choose to engage with timely issues" ${ }^{\text {. To stimu- }}$ late discussions pertaining to artists' agency and the convergence between art and activism in the present, the selected films offered a historical contextualization of social and political issues in Québec and Canada that were brought into public view by artists in the past. The film screenings provided a forum to explore related themes, which ranged from consumer culture, youth culture, and anti-colonialism, to student protests, first nation issues, poverty, access to media, and cultural preservation. At its core, the programmed films presented art's connection to everyday experiences with themes that explored social, political and philosophical questions.

Films such as Claude Jutra's Rouli roulant (1966) and Michel Brault's Le temps perdu (1964) announced a new youth culture, fused with idealism and rebellion in 1960s Québec. Films by Arthur Lipsett (Very Nice, Very Nice, 1961; Free Fall, 1964; A Trip Down Memory Lane, 1965), Julian Biggs (23 Skidoo, 1964), and by Jean-Thomas Bédard (This is a Recorded Message, 1973) were also screened. All of these examples are artistic experimentations that convey anxieties associated with modern city life. A conceptual thread throughout the weekly screenings were themes related the power of communication (spoken word, television, film, and radio) as a method of expression for ideas and concerns: The Songs of Chris Cobb (Colin Low, 1967), VTR St. Jacques (Bonnie Sherr Klein, 1969) and Night Mayor (Guy Maddin, 2009). As a critical investigation on the theme manifestation/demonstration, more overtly political films were also screened, including Speak White (Pierre Falardeau \& Julien Poulin, 1980), based on Michèle Lalonde's powerful poem against oppression, Occupation (Bill Reid, 1970), a short documentary on striking political science students at McGill University, and You are on Indian Land (Mort Ransen, 1969), a film report about the 1969 protest demonstration by Mohawks of the St. Regis Reserve near Cornwall, Ontario. (fig. 1) Each screening series, which ran for approximately one hour, not only provided a socio-historical context to the then ongoing student movement, but also served as a celebratory acknowledgement of the artistic experimentation and rich filmic heritage of Québec and Canada. Furthermore, the series of films were preceded by a short reception, as a way for participating artists and the public to engage in informal conversations prior to the screenings. The courtyard space occupied a distinct presence by encouraging city walkers to spontaneously take a pause from their daily activities and watch a film or films. These types of dynamics inspired the Recto/Verso Collective and participating artists to constantly shift and respond to the possibilities of place-making in the gallery spaces and in the adjacent courtyard.

In building the programming for the outdoor screening series, the Recto/Verso Collective felt that certain feature films from the NFB catalogue strongly supported the Recto/ Verso theme of manifestation and demonstration. Due to the length of these films, the programming collective decided to present them in rotation in the gallery's black box. The four selected black box films thematically paralleled the four weekly screening series as an extended dialogue. These seminal films were Le chat dans le sac (Gilles Groulx, 1964), L'Acadie, L'Acadie?!? (Michel Brault and Pierre Perrault, 1971), Kanehsatake: 270 Years of Resistance (Alanis Obomsawin, 1993), and 24 heures ou plus (Gilles Groulx, 1973). All of the programmed films for both the outdoor and the black box screenings are available for viewing on the NFB website. By presenting these works within the framework of Manifestation/Demonstration, Recto/Verso Collective hoped that visitors who were not familiar with these significant québecois and Canadian films would be inspired to engage with them outside of the gallery programming. 
The programmed films span across different themes, locations, and periods. Through the presentation of concerns and struggles from different communities, these films were meant to consider how the present student movement is situated in recent québécois and Canadian history. At the same time, the film series parallels the various discussions on the relationship between art and politics that actively took place during the span of the residency/exhibition.

\section{Participate, Create, Share, and Connect}

As part of the conceptual basis of the studio intensive, Recto/Verso Collective considered ways for visitors to contribute to the ongoing artistic research and creation being conducted by École de la Montagne Rouge in the work/ exhibition spaces. Author Nina Simon defines a "participatory cultural institution as a place where visitors can create, share, and connect with each other around content" ${ }^{10}$. To create, share, and connect requires various forms of engagement. Consequently, in developing the programming, the Recto Verso Collective considered different ways publics can participate in the studio intensive. Simon elaborates further on these different types of engagement:

Create means that visitors contribute their own ideas, objects, and creative expression to the institution and to each other. Share means that people discuss, take home, remix, and redistribute both what they see and what they make during their visit. Connect means that visitors socialize with other people—staff and visitors-who share their particular interests. Around content means that visitors' conversations and creations focus on the evidence, objects, and ideas most important to the institution in question ${ }^{11}$.

During the development of the programming, the Recto/Verso Collective considered different relationships between the artistic activities or events, and the situated space and its publics. As discussed earlier, the courtyard acted

10 SIMON, Nina. The Participatory Museum. Santa Cruz, CA: Museum 2.0, 2010, p. ii. as a direct conduit to the public and provided a relaxed space for fostering visitor participation. Inspired by ideas related to labour and systems of communications, the programming collective arranged an informal installation consisting of a patio chair and table furnished with a typewriter in the courtyard each day. Next to the typewriter was a bilingual sign with the following question: "Manifestation/ Demonstration. What does this mean to you? Share your responses, aspirations, desires, ideas, ideals...”. Using the typewriter, visitors were able to share their reflections on a roll of paper. The roll format was used instead of single sheets of paper, as a direct way for visitors to read previous responses. It also suggested a response not only to the original prompt, but to other visitor's responses as well.

(fig. 2) This antiquated technology was installed in a street courtyard to trigger the interest from city passersby. The typewriter installation invited visitors to share their experiences within defined boundaries. "Meaningful constraints motivate and focus participation" 12 while ensuring visitors control over the content they provide. During the course of the studio intensive, the public typed their responses to the question but also responded to the residency/exhibition and student movement at the same time.

\section{Gallery as Atelier}

The studio intensive format is intended for artists in residency to use the gallery as a work site as well as an exhibition space. Within this constant flow between process and display, are opportunities for exchange between artists and publics. Visitors were able to participate in the artists' working spaces during open silk-screening workshop sessions. These sessions were announced to the public through the gallery's website and social media, which invited visitors to bring paper or fabric on which to screen print with the artists in residence. The open silk-screening workshops 


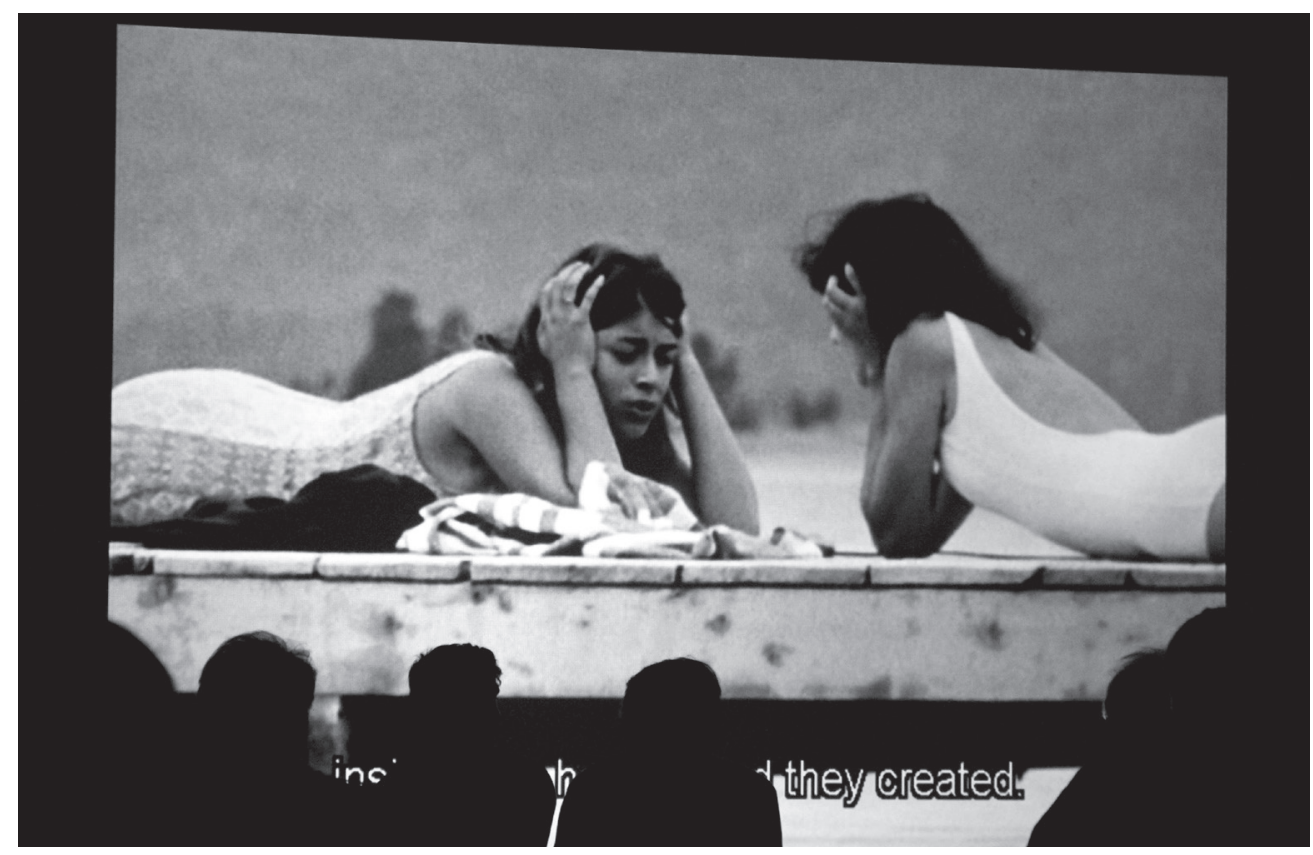

Figure 1

Outdoor film screenings. Film still Le temps perdu

(Michel Brault, 1964, NFB).

(C) Recto/Verso Collective [Photographer: Tina Carlisi]

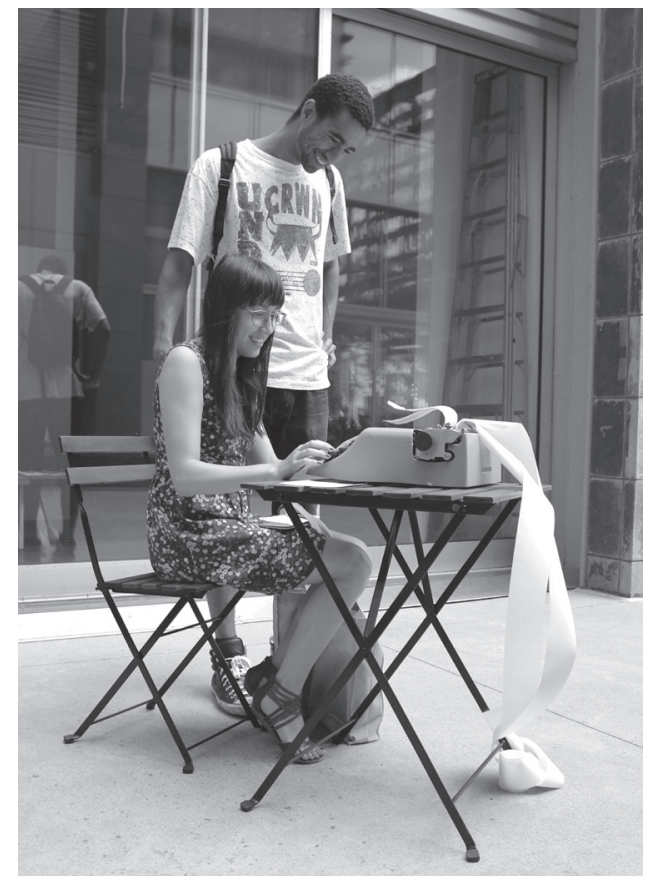

Figure 2

Visitors using the typewriter.

(c) Recto/Verso Collective [Photographer: Tina Carlisi] 
were typically between two and four hours and held while the artists in residence were producing their work. Having an integrated approach to the artist residency and public activities resulted in a continuous activation of the gallery spaces. For visitors who were not aware of the open workshops, it presented a choice to either observe the artists during their production of posters, which were created for both the constantly rotating gallery display and the street manifestations, or to participate in the screen-printing of posters. The informal set up of a silk-screening atelier within a white box gallery also created a conversational space between the artists, the programming collective and its publics.

(fig. 3) During their working sessions, members of École de la Montagne Rouge would collaboratively design new images for posters, prepare screens, research inspiring texts and images, silk-screen, experiment with materials, work on website communications, and develop rotating installations in the gallery spaces. Collaboration is an open-ended concept that includes diverse working methods. In contemporary art, the "field has expanded and developed affinities with a number of methods inspired by activism"13. With much of contemporary practices focusing on collaborative, participatory, and social forms, what was unique about École de la Montagne Rouge's participation in Manifestation/Demonstration is that they are not an artist collective inspired by activism, or what artist and activist Josh MacPhee refers to as "fetishizing activist culture" ${ }^{14}$, but rather they are artist-activists producing work for a specific cause. Their mode of production differs from social art practice, which generally does not place importance on objects but rather on an interaction as a means to bring awareness on a concept or cause. On the contrary, École de la Montagne Rouge utilized the poster as a powerful medium that can bring awareness by participating in a socio-political collective effort to contest the proposed tuition hikes.

(fig. 4) With the then ongoing student movement, it was critical for École de la Montagne Rouge to maintain an active role. For them, participating in Manifestation/Demonstration allowed them to occupy a new space outside their immediate community, which is Université du Québec à Montréal (UQAM). From the onset, École de la Montagne Rouge expressed that they did not want to create an exhibition in the traditional sense because the strike was actively ongoing, but rather use the space for production and dialogue. Many of the elements they used for street manifestations were present in the gallery, such as placards and a large metal frame cube covered in red fabric, which was temporarily used in the gallery, as an area for silk-screening.

(fig. 5) École de la Montagne Rouge's serious commitment to the movement and to artistic production was also evident in their apparel. Members of the collective wore orange worker overalls with "École de la Montagne Rouge" silk-screened on the backside. Each workday at the FOFA Gallery, members of the group would slip into their jumpsuits before starting their artistic production, which visually communicated their role as artists as cultural workers. For art historian and critic Claire Bishop, "politically engaged collaborative practice constitutes today's avant-garde" 15 . Through their actions, research and artistic production, École de la Montagne Rouge builds upon historical avant-garde practices, and presents them in innovative contemporary forms. The adoption of worker apparel references avant-garde ideals explored by Russian Constructivist artists, specifically Alexander Rodchenko's Production Clothing (1922).
13 BILLING, Johanna, Maria LIND, and Lars NILSSON. Taking the Matter into Common Hands: On Contemporary Art and Collaborative Practices. London: Black Dog Publishing, 2007, p. 203.
14 THOMPSON, op.cit., p. 31.

15 BISHOP, Claire. "The Social Turn: Collaboration and its Discontents”. Artforum, vol. 44, no. 6, 2005, p. 179. 


\section{Gallery as Street}

The FOFA Gallery has four distinct spaces and two adjacent areas, which were all activated during Manifestation/Demonstration. Within the FOFA Gallery, there is the main gallery space, a black box, which is often used for projected works, a street vitrine and an interior corridor vitrine. The two adjacent areas are the exterior courtyard and an atrium space, which the FOFA Gallery reserves as a reception area for vernissages [openings] or other exhibition related events. During Manifestation/ Demonstration, the main gallery space was activated as the atelier and the two vitrines were used as display spaces. The relationship between the street and vitrines was closely considered, especially during a time when the city was adorned with red squares, posters, and stenciled slogans on the sidewalks in support of the student movement. The vitrines are windowed public spaces that are also visible to passersby outside the gallery's regular hours. The interior vitrines, referred to as the "York corridor vitrines", span a length of approximately one hundred and fifteen feet. This expanded area was treated as a dialogic space by École de la Montagne Rouge.

The collective installed video projections, large plywood boards for poster wheat pasting, small working tables, institutional furniture and an overhead projector, which projected the phrase "Restons unis" (Stay united) throughout the studio intensive. This projection stood as a poetic reminder of the power of unity and the possibilities of collaborative relationships between communities who are in support of the same cause. The collective also painted a large arrow on one of the walls using blackboard paint and often used it as a zone for group brainstorming. Daily passersby and visitors would see members of the collective working in the vitrines and, like city construction sites plastered with posters, École de la Montagne Rouge would continuously wheat paste their posters on the wall-mounted plywood surfaces.

16 KESTER, Grant. Conversational Pieces: Community and Communication in Modern Art. Berkeley, CA: University of California Press, 2004, p.12. (fig. 6) Inherently political, their installations asked critical questions and sometimes these questions were asked in an overt manner. École de la Montagne Rouge's posters have an empowering presence with messages about unity and mobilization. Not unlike the posters of May 68, École de la Montagne Rouge's posters are deeply poetic, such as their rendition of the Québec flag with a white dove wearing a red square, for example. One of the posters the collective produced during the studio intensive, and which was wheat-pasted in the York corridor vitrines, included the questions: "Why are French Canadians always on strike? Why are English Canadians never on strike?" Their intention was not solely to provoke but rather to invite a political dialogue. It incited a "discursive exchange" 16 between the Recto/ Verso Collective and École de la Montagne Rouge, prompting discussions on the historical divides between Anglophone and Francophone communities, and how the climate of Québec in the 1960s became a critical site for debate and social change ${ }^{17}$. Also discussed were the complexities that are present in the make up of québécois society, from first generation populations to First Nations. The choice of referring to "French Canadians" instead of Québécois in this poster also triggered conversations about the historical determinism of the québécois identity.

(fig. 7) Understanding the context of the FOFA Gallery as a critical site for artistic creation and research, the Recto/Verso Collective had no intention of censoring this work. Instead the programming collective welcomed visitors who were intrigued and even upset to discuss their positions. One visitor came in with a note in hand to give to the artists. The Recto/ Verso Collective encouraged this visitor to also re-type the note on the typewriter in the courtyard as a trace for others to read. These types of engagements were not planned in a formal sense, but consciously facilitated through the programming framework. This mode of dialogue perhaps cannot be replicated, especially in galleries or museums whose mandate includes

17 WARREN, Jean-Philippe. Une douce anarchie: Les années 68 au Québec. Montréal, QC: Boréal, 2008. 


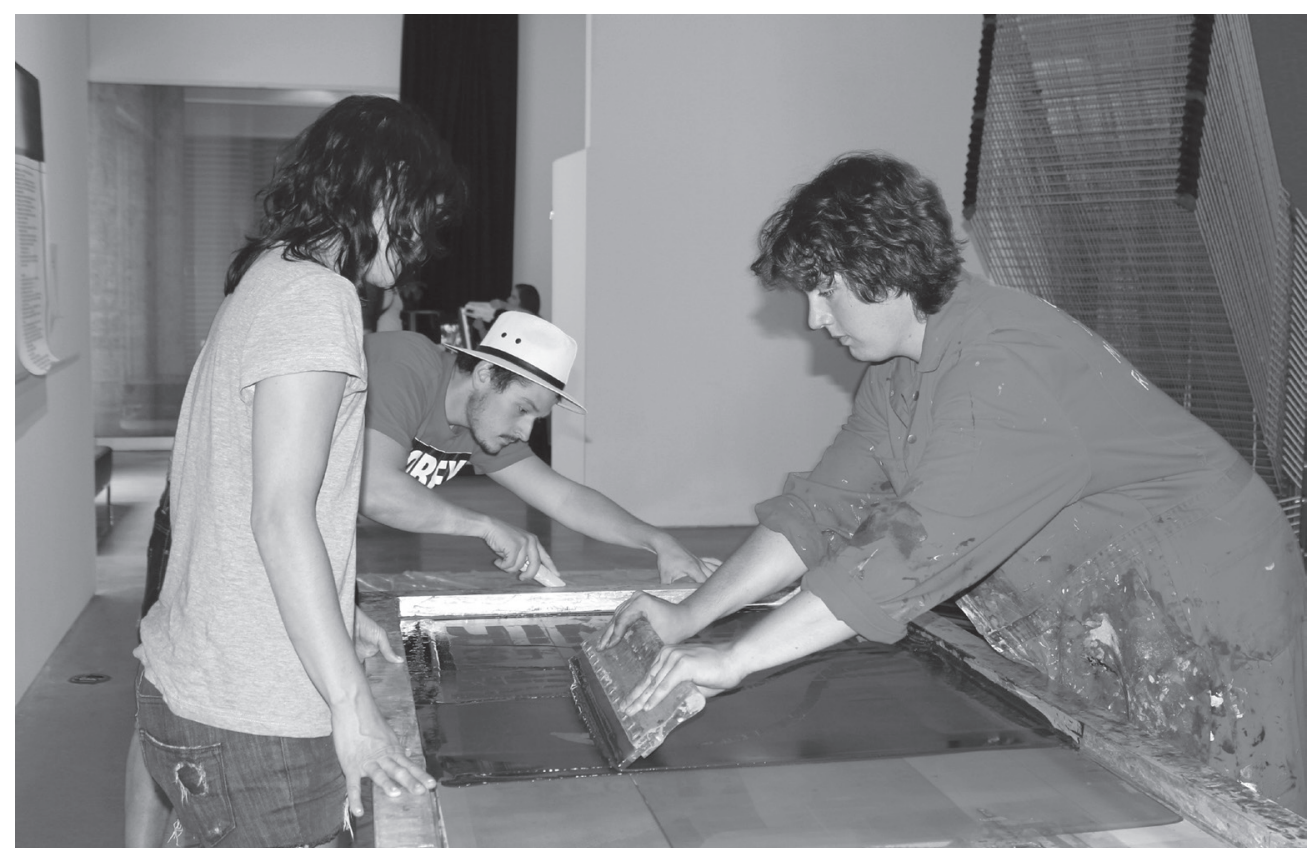

Figure 3

Open silkscreening workshop with École de la

Montagne Rouge .

(c) Recto/Verso Collective + École de la Montagne Rouge

[Photographer: Tina Carlisi]

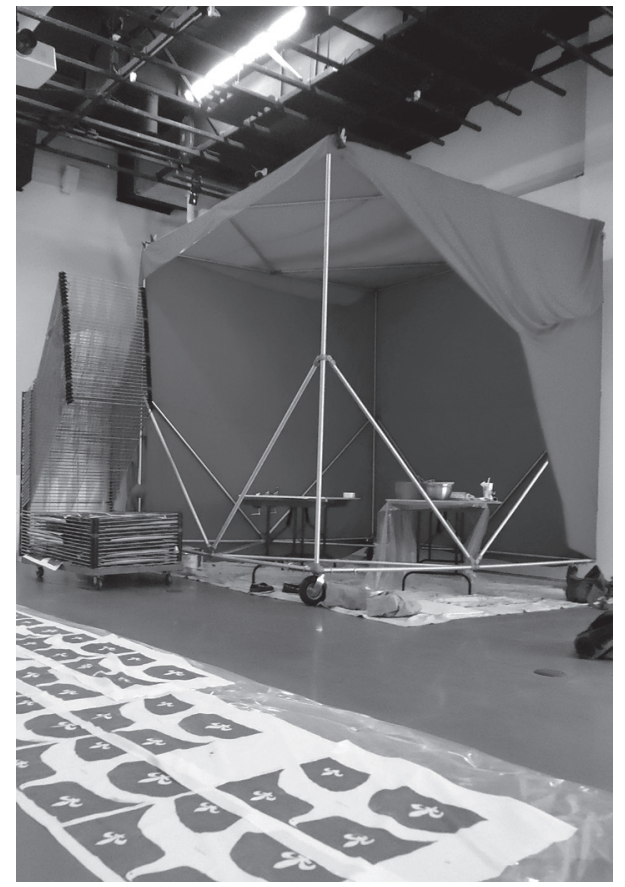

Figure 4

Red cube silkscreening zone by École de la Montagne Rouge.

(c) Recto/Verso Collective + École de la Montagne Rouge [Photographer: Tina Carlisi] 


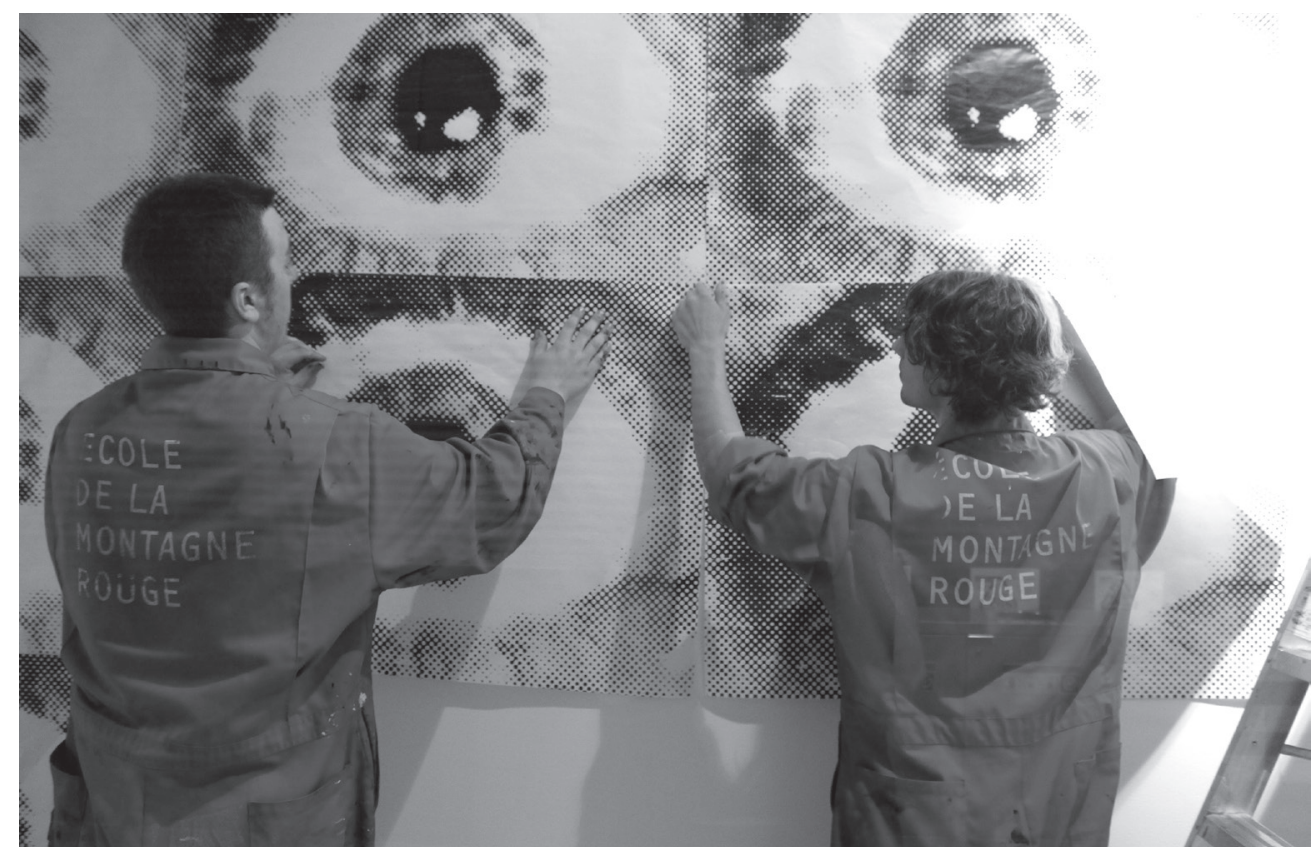

Figure 5

École de la Montagne Rouge in the York corridor vitrines.

(C) Recto/Verso Collective + École de la Montagne Rouge

[Photographer: Tina Carlisi]

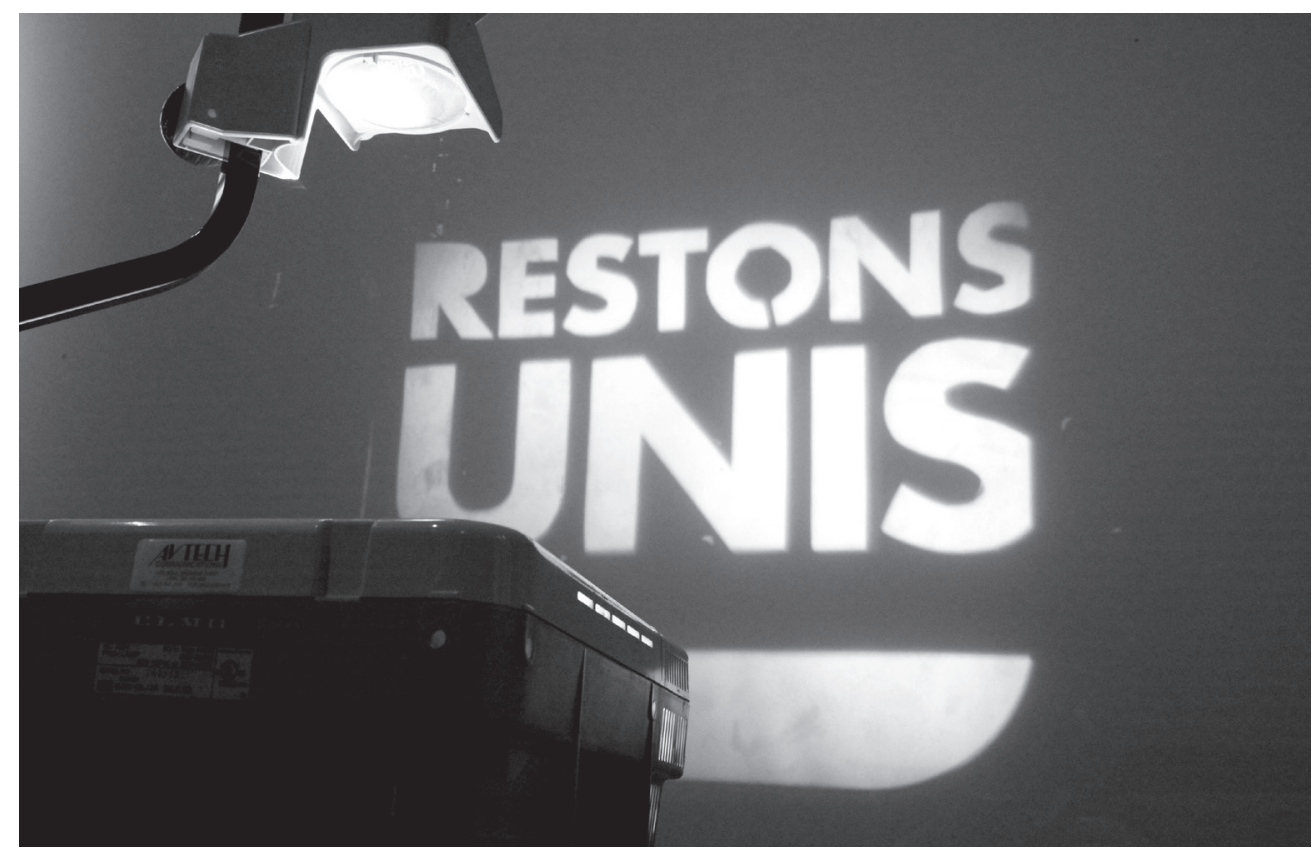

Figure 6

Restons Unis by École de la Montagne Rouge.

(c) Recto/Verso Collective + École de la Montagne Rouge

[Photographer: Justin Lapointe] 


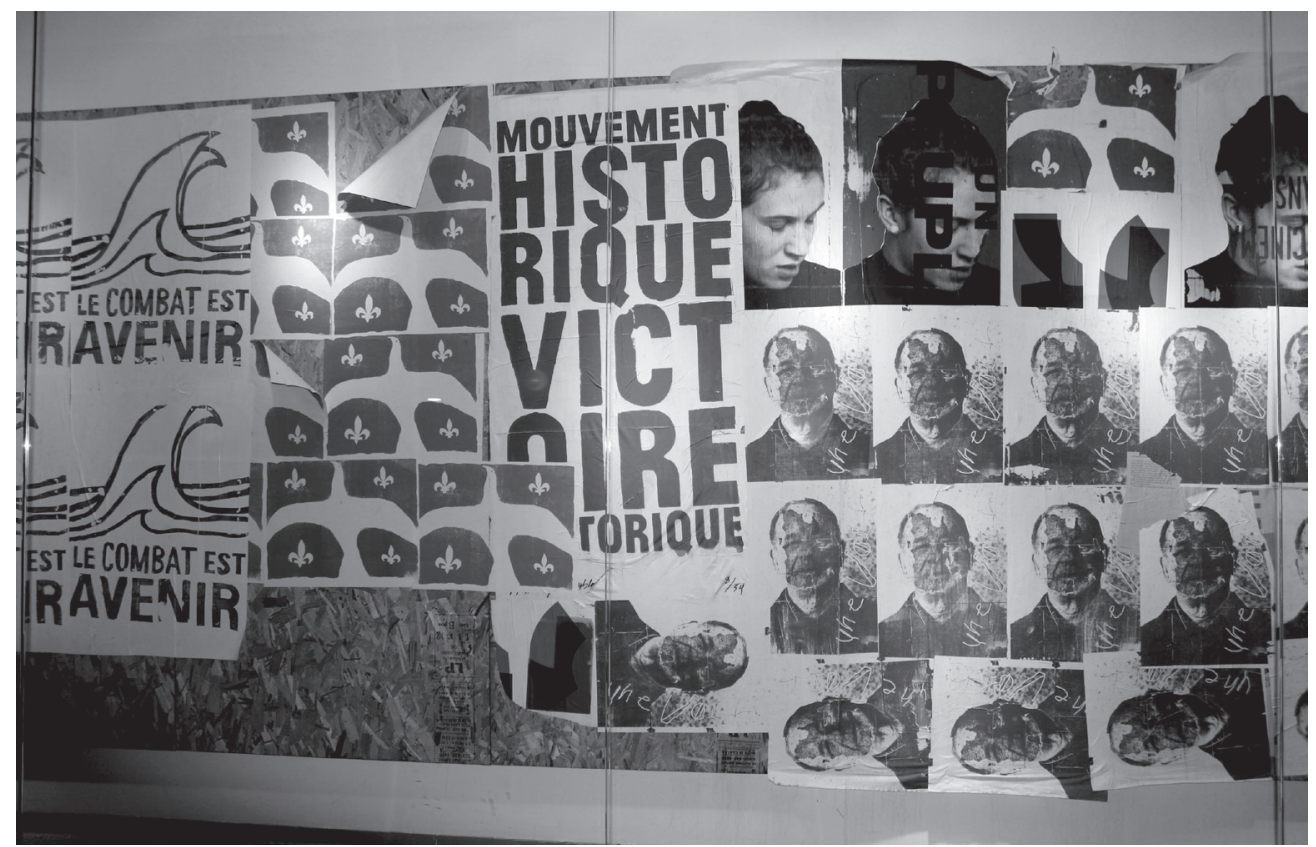

Figure 7

Poster installation in York corridor vitrines by École de la Montagne Rouge.

(c) Recto/Verso Collective + École de la Montagne Rouge

[Photographer: Tina Carlisi] 
educational programming for younger audiences, but in Manifestation/Demonstration, the programming collective wanted to investigate the intersections between activism, art, design and pedagogy in an open and structured format developed for the studio residency.

These types of conversations between the artists and the programming team further strengthened the position that art occupies an important role in contemporary social movements. Furthermore, the residency/exhibition brought two initiatives together, École de la Montagne Rouge and Recto/Verso Collective, who share similar values, regardless of perceived cultural differences. From a pedagogical point of view, the various ways that dialogue unfolded, whether in conversation, workshops or interactive prompts, offered a layered approach to the residency/exhibition in ways that could not have been wholly foreseen. However, creating open spaces in the programming supported these unpredictable forms of dialogue.

\section{Vernissage/Finissage}

At the end of Manifestation/Demonstration, a vernissage/finissage (opening/closing) was held. In conceptual continuity with the notion of recto/verso as two sides, it was a finissage for École de la Montagne Rouge's residency/ exhibition but also a vernissage for a group of Mexican women living in Montréal that the Recto/Verso Collective had invited for the evening to create a participatory work. Similar to the Québec Spring, a student movement

18 In May 2012, a group of students at the Universidad Iberoamericana in Mexico City booed presidential candidate Enrique Peña Nieto, who belongs to the Partido Revolucionario Institucional, PRI (Institutional Revolutionary Party) that, under the succession of many presidents, has been in power for 71 years. After this incident, supporters of the PRI in the mainstream media demonized the dissenting students, claiming they were planted by their political rivals. 131 students from the university fired back by uploading videos on YouTube where they proved their identity by holding up their student ID cards. The name "Yo Soy \# 132 (I am \# 132)" is a symbol of solidarity with the students who stood up to Peña. The protests quickly spread from social media to mass street manifestations in Mexico City. Source: Occupy Wall Street. \#TodosSomos132: Solidarity With the Mexican Spring. < http:// occupywallst.org > (retrieved on January 15, 2013) called Yo Soy \# 132 (I am \#132) $)^{18}$ was gaining intensity in Mexico during the spring and summer of 2012. We invited a collective of Mexican artists to develop an event in reference to Yo Soy \#132, and offered a forum to consider how current social movements can parallel each other. These different movements are in reaction to specific socio-historical and economic contexts, but share a common struggle against the effects of neoliberalism ${ }^{19}$ on education.

The collective made a large piñata in the form of a cornucopia, similar to the map of Mexico. The work was a gesture that represented a series of complex social and political issues that Mexico is currently going through. "Symbolic gestures can be powerful and effective methods for change" ${ }^{20}$. The title of this participatory work, No pierdas el tino (Don't lose your aim), is a reference to a line taken from a traditional Mexican song that is sang during the turning and smashing of the piñata. It is also a social and political commentary on the idea of never losing focus on collective social goals. The collective described their project as being "a collaborative and participatory project that intends to break the tension and release intentions through art and creative processes, not only by exposing social and political problems, but also by looking together for possible solutions" ${ }^{21}$. Within the theme of recto/verso, where recto is the front and verso is the back, the collective also saw it as a notion of interior/ exterior, or what is shown and what is hidden.

19 "Neoliberalism is the defining political economic paradigm of our time-it refers to the policies and processes whereby a relative handful of private interests are permitted to control as much as possible of social life in order to maximize their personal profit. Associated initially with Reagan and Thatcher, neoliberalism has for the past two decades been the dominant global political economic trend adopted by political parties of the center, much of the traditional left, and the right. These parties and the policies they enact represent the immediate interests of extremely wealthy investors and less than one thousand large corporations." CHOMSKY, Noam. Profit Over People: Neoliberalism and the Global Order. New York: Seven Stories Press, 1999, p.7.

20 THOMPSON, op. cit., p.18.

21 FOFA Gallery. Recto/Verso II: Manifestation/Demonstration. <www.fofagallery.concordia.ca> (retrieved January, 2013). 
(fig. 8) Before the vernissage/finissage, the Mexican artists worked on finishing the piñata in the courtyard, decorating it with images of Emiliano Zapata and other images of revolutionary Mexico, as well as posters and newsprints by École de la Montagne Rouge. Visitors were welcome to participate in the adorning and stuffing of the piñata, which included candy, toys, and wooden clothes pins dressed with a fabric t-shirt with the phrase "Yo soy \#132". Similar to the red square used as a symbol for the Québec student movement, the wooden clothes pins shaped as a person with "Yo Soy \#132" is a symbol of the ongoing student movement in Mexico. In preparation for the vernissage/finissage, the artists from Mexico decorated the main gallery space with a stream of decorative tissue paper in green, white and red: the colors of the Mexican flag. École de la Montagne Rouge also decorated the main gallery space with a stream of Québec flags they made represented by a white dove wearing a red square on a blue background. These two streams joined in one point in the spirit of solidarity between the two student movements. The piñata was collectively hung for the purpose of smashing it together later in the evening, while members of École de la Montagne Rouge prepared for an on site t-shirt silk-screening session for the public while other members made special seats from found wood palettes for the last outdoor film screening series taking place the same evening.

\section{(fig. 9) The multiple events during the} vernissage/finissage- $t$-shirt silk-screening, piñata breaking, film screenings, and reception-drew a diverse crowd who participated, collaborated, and conversed with the invited artists, the programming collective and with each other. Visitors brought their t-shirts to be silk-screened and then sang and smashed the piñata. The Mexican artist collective provided a sheet with lyrics from the traditional piñata breaking song in Spanish as well as in English and French translations. The festive spirit of singing in a circle with gallery visitors of all ages, as different people from the audience took turns in hitting the piñata while blindfolded, was a deeply profound moment in Recto/ Verso: Manifestation/Demonstration. "Social practice artists create forms of living that activate communities and advance public awareness on pressing social issues" 22 . Allowing for an open structure in the studio intensive, and in constant conversation between the artists and the programming team, all participants collectively built upon a common belief in the powerful role art can play during social movements. Different perspectives were heard, discussed, and debated; these exchanges deepened a sense of solidarity, even in the moments when differing perspectives were voiced. The programming collective foresaw the importance of documenting Manifestation/Demonstration and sharing it with a larger audience as it unfolded. Similarly to the student movement, the residency/exhibition was in constant flux, with shifting ephemeral activities.

\section{Documenting Art/Action}

Manifestation/Demonstration was documented daily, from the first to the last day of the studio intensive. One of the challenges of documenting a studio intensive is maintaining a balance where the photographer is not obtrusive to the creative process. As Pablo Helguera notes, [d] ocumentation should be regarded as inextricable component of an action, on which, ideally, becomes a quotidian and evolving component of the event, not an element of postproduction but a coproduction of viewers, interpreters, and narrators. Multiple witness accounts, different modes of documentation, and most importantly, a public record of the evolution of the project in real time are ways to present an event in its multiple angles and allow for multiple interpretations ${ }^{23}$.

23 HELGUERA, Pablo. Education for Socially Engaged Art: A Materials and Techniques Handbook. New York: Jorge Pinto Books, 2011, pp. 75-76. 
Documenting artists within the context of this residency/exhibition required certain considerations for discussion amongst the participants. The documentation was predominately done by the Recto/Verso Collective, though at times the group would hand over their camera to a member of École de la Montagne Rouge. The photographs taken by a member of her or his own collective resulted in intimate and experimental images, adding a unique aspect to the documentation process.

(fig. 10) Due to the active nature of the residency and educational programming, Recto/ Verso Collective used social media in order to document and expand interaction. They started a Tumblr site for posting the documentation of daily activities and announcing upcoming ones on a regular basis. The Tumblr site offered an expanded version of the information posted on the gallery website and an effective method for sharing through social media. Recto/Verso Collective also utilized FOFA Gallery's Twitter account for immediate communications for events such as the film screening series, t-shirt silk-screening and piñata breaking. Documenting the unfolding of Manifestation/Demonstration resulted in an extended dialogue between the artistic production that took place, the artists, the programming collective and its publics. In hindsight, visual documentation offered the possibility to reflect upon the dynamic process Manifestation/Demonstration embodied in its short conception and execution within the spirited climate of the student movement.

\section{Manifestation/Demonstration Publication}

In November 2012, the FOFA Gallery produced a limited edition boxed set of small format publications titled LES CAHiERS, in conjunction with the exhibition Contested Site: Archives and the City. The Recto/Verso Collective produced a bilingual publication as part of LES CAHiERS titled, Manifestation/ Démonstration: Collectif Recto/Verso Collective
+ L'École de la Montagne Rouge. The curatorial team for Contested Site, Christopher Moore and jake moore, described the exhibition as highlight[ing] the emerging phenomenon of research/creation, which is redefining institutions, pedagogy, funding agencies and artistic practice in a reflexive manner, as perhaps a contested site itself .... the exhibition framework is discursive, laying bare the networks, individuals, and communities that collectively construct the perceived whole, while concurrently amplifying the distinct methodologies and media required to do $\mathrm{so}^{24}$.

In parallel to the publication, the Recto/Verso Collective invited École de la Montagne Rouge to exhibit a new work in FOFA Gallery's SteCatherine street vitrine for the Contested Site exhibition. They presented a work titled Teri Tane Note Miti, which was a wall installation of images from their Tumblr site, arranged to give a sense of the scrolling and downloading of the website page, offered as another way of thinking about their artistic production.

The opportunity to produce a publication about Manifestation/Demonstration presented an optimised form for reflecting on the Recto/ Verso residency/exhibition. The assembly of image and text in print format allowed for the actual translation of the traces within the studio intensive as it relates to the whole. The layout design for the Manifestation/ Demonstration publication alternates between English and French, between artists, activities and elements of the programming, representing fluidity between art, design politics, and educational/curatorial programming.

\section{Stay United}

Manifestation/Demonstration brought multiple entry-points for conversations in addressing socio-political movements and the agency of artists within these movements. Recto/ Verso was intended as a spirited on-site project 
that paralleled and dialogued with the manifested actions of the student movement. The studio intensive presented possibilities offered by collectives working in a dialogic framework in times of political change and an experiment in the adaptation of an unfolding residency/ exhibition. The multiple activities within the studio intensive did not solely rely on visitor participation, which, in its absence can create stagnation within an exhibition. Rather, the exhibition presented a structured and open framework for the artists, the programming collective, and its publics to flow between process and presentation. The visual documentation of Manifestation/Demonstration became an expanded field within the project, through the dissemination of daily documents of the residency/exhibition to a larger public. The Internet, and specifically social media sites, point to "collective desires to create new areas of conviviality and introduces new types of transaction with the cultural object" ${ }^{25}$. In its final iteration, the publication, produced within an investigative curatorial project on contemporary art and research, allowed for reflection on Manifestation/Demonstration as a connected whole.

This author does not propose that art should always be political or activist in its application. Rather, the main question is: what can be learned from cultural practices during times of social change? The Quebec Spring provided a unique environment for artistic exploration and expression. Social movements offer a ground for knowledge production ${ }^{26}$ that creates a continuous process of learning for those involved. In the context of Manifestation/Demonstration, the movement inspired the development of collaborative and dialogic methodologies in gallery programming and education. By constantly shifting and balancing a space for artists to produce and exhibit work, programming events such as the film series and silk-screening sessions, this

25 BOURRIAUD, Nicolas. Relational aesthetics. Dijon: Les presses du réel, 2002, p. 26.

26 CHOUDRY, Aziz and Dip KAPOOR. Learning from the ground up: Global perspectives on social movements and knowledge production. New York, NY: Palgrave Macmillan, 2010 , p. 2 . experience foregrounds the importance of presenting contemporary art as an active force. The programming closely modeled artistic methods of working and required time for the whole residency/exhibition to unfold. Through this unfolding of work, activities and events, the programming team needed to adopt a reflective practice that included extensive documentation and conversations on how to adapt to the daily changing activities.

École de la Montagne Rouge's artistic contribution to a movement imbued with a youthful vision for preserving accessible education, a battle that was fought for nearly fifty years prior to this movement and arguably under threat by neoliberal politics ${ }^{27}$, inspired a desire to examine the poetics of the political. The recto/verso format is not based on notions of duality, but rather provided a method for investigating the vast scope between the various themes and forms explored throughout the studio intensive. At their foundation, artistic practices involve forms of participation, collaboration, and dialogue that reflect a philosophical questioning of the place of the artist and her or his role in contemporary society ${ }^{28}$. The unique dynamic of collectives working together from different communities within the same city acted as a poetic assertion that art can have the profound potential to unite.

27 BAILLARGEON, Normand. Je ne suis pas une PME: Plaidoyer pour une université publique. Montréal, QC: Éditions Poètes de brousse, 2011, p.21.

28 COSSENS, Kathleen, Darla CRISPIN, and Anne DOUGLAS. The Artistic Turn: A Manifesto. Belgium: Orpheus Instituut; Leuven: Leuven University Press, 2009, p. 17. 


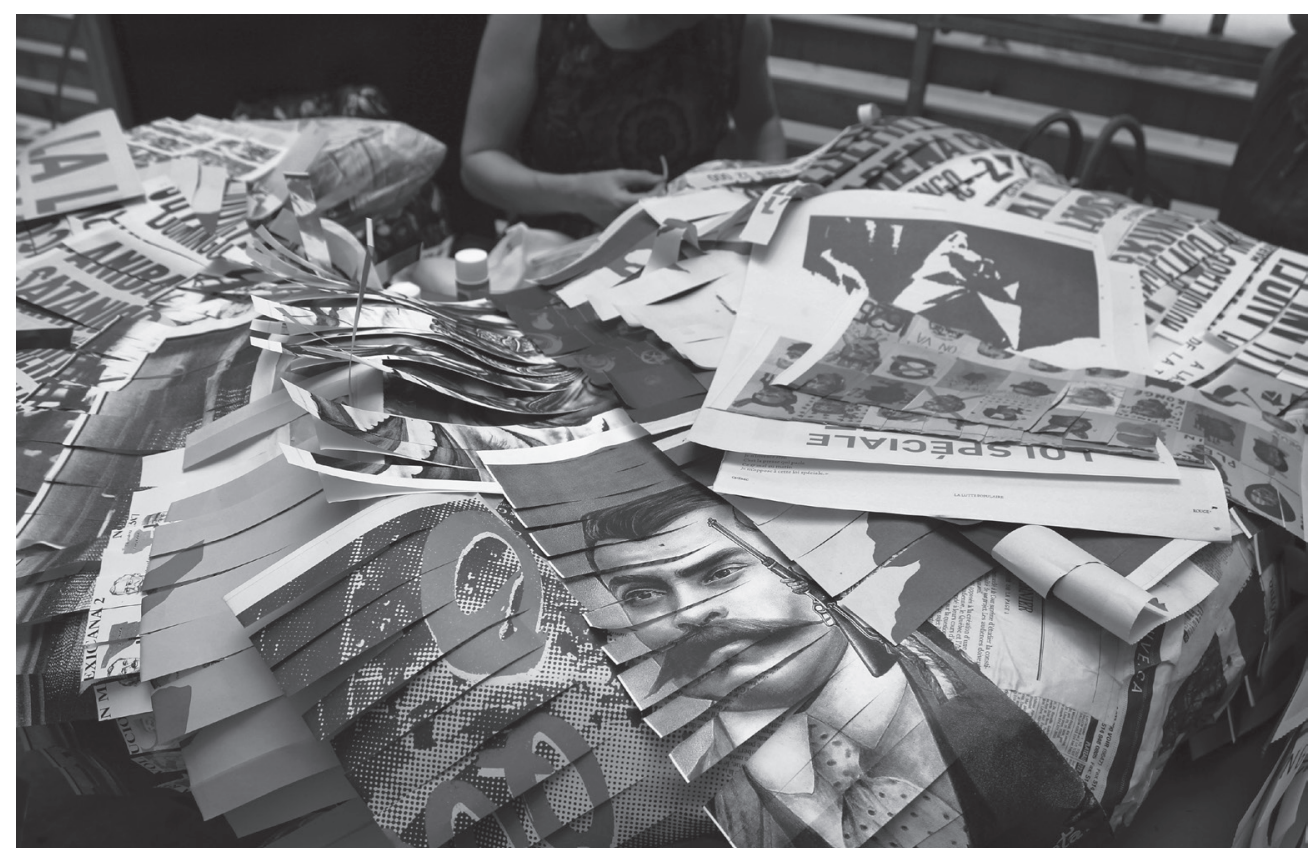

Figure 8

Decorating the piñata.

(C) Recto/Verso Collective + Maria Ezcurra.

[Photographer: Tina Carlisi]

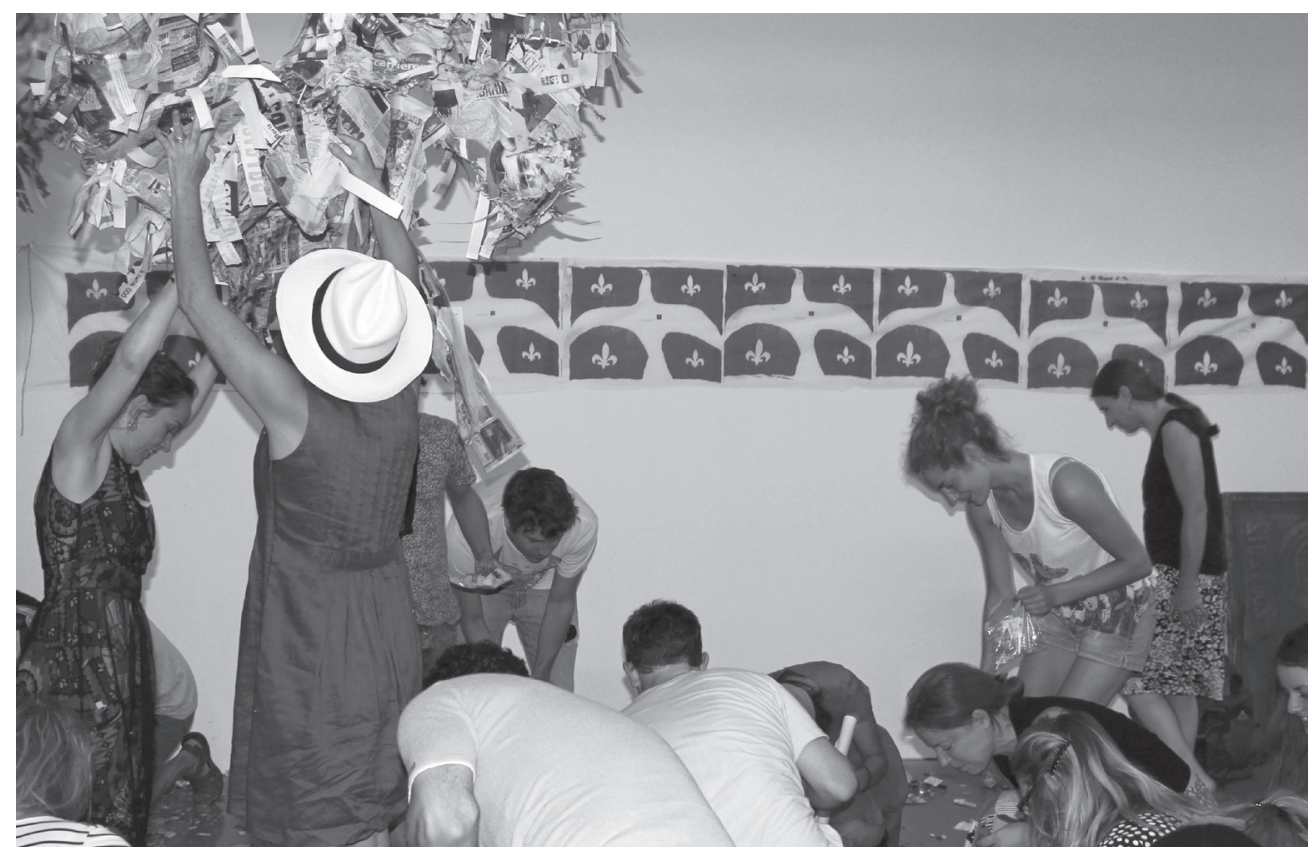

\section{Figure 9}

Breaking the piñata.

(C) Recto/Verso Collective +Maria Ezcurra.

[Photographer: Tina Carlisi] 


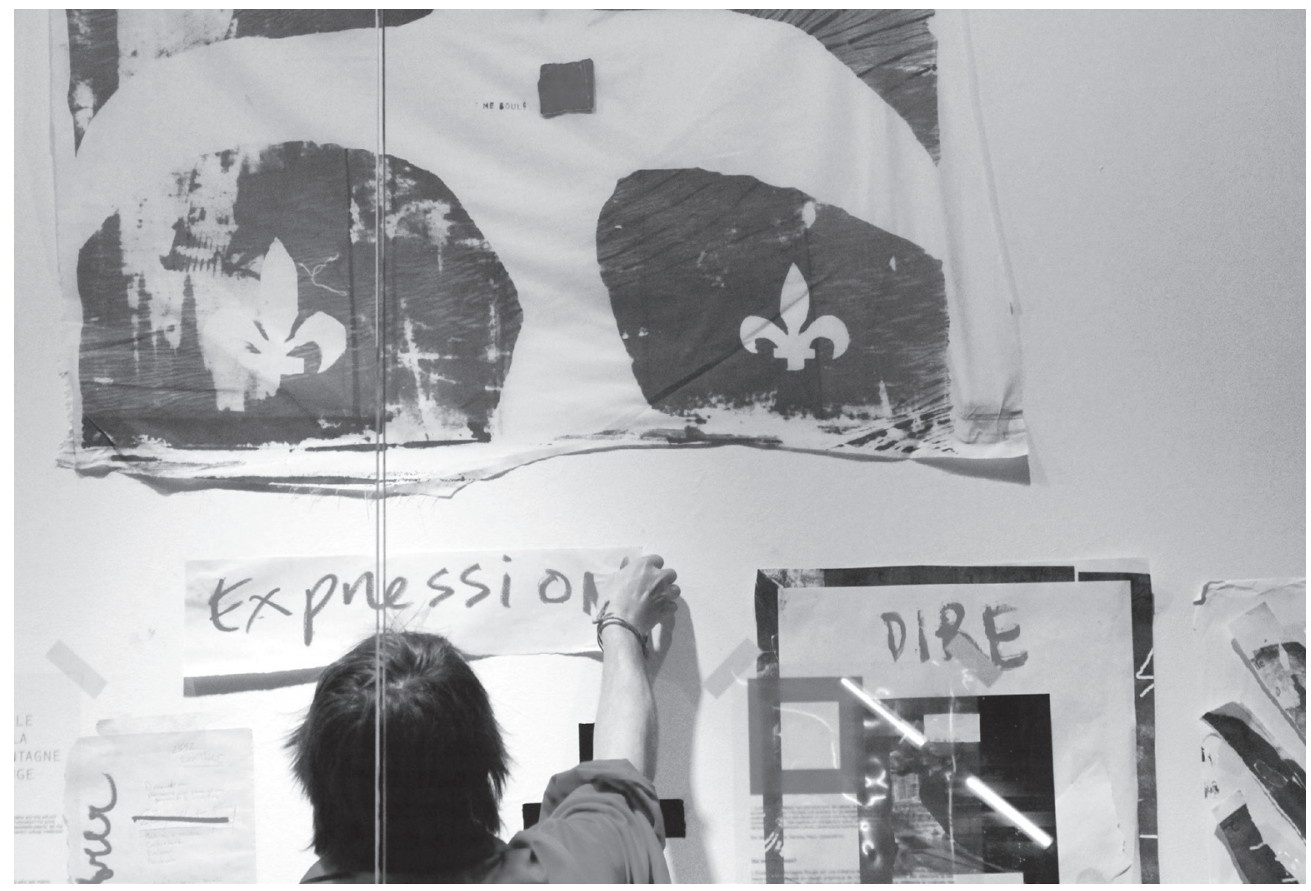

Figure 10

École de la Montagne Rouge in the York corridor vitrines.

(c) Recto/Verso Collective + École de la Montagne Rouge

[Photographer: Justin Lapointe] 
Tina Carlisi, traduit par Micheline Giroux-Aubin et

Alessandra Mariani

\section{Art/Action: Dialogue avec le mouvement "printemps érable" au Québec}

Au printemps 2012, la Galerie de la Faculté des beaux-arts (FOFA) de l'Université Concordia avait organisé Recto/Verso : Manifestation/ Démonstration, un atelier-laboratoire intensif de quatre semaines et une plateforme de dialogue avec le mouvement étudiant à l'œuvre durant cette période. Le collectif en charge de la programmation de l'événement, composé de Tina Carlisi, Joshua Fourney et Katerina Lagassé, en collaboration avec le directeur de la Galerie, jake moore, avait considéré l'activisme montant au Québec comme point de départ pour approfondir l'étude des répercussions des manifestations et démonstrations, et des concepts généraux qui les sous-tendent.

Pendant cette activité, la Galerie FOFA a servi de plateforme de dialogue, en considérant la pluralité des voix qui composent ces discours, quelles soient centrales ou périphériques aux diverses phases du mouvement. Le collectif à l'origine de Recto/Verso, en collaboration avec l'École de la Montagne rouge ${ }^{1}-$ un autre collectif-, a expérimenté diverses façons d'utiliser les espaces de la galerie comme lieux de rassemblement, d'aménagement, de production et d'échanges. La programmation, qui fournissait des points d'accès à de multiples visions socio-politiques et historiques, consistait en un environnement en constante évolution dans la galerie, dont des ateliers de sérographie, des activités participatives avec d'autres artistes et une série de projections extérieures de films produis par l'Office national du film du Canada (ONF).

Cet article porte sur le contexte pédagogique, participatif et collaboratif de la programmation d'une galerie d'art contemporain ainsi que sur les activités de recherche en tant que moyens de générer le dialogue entre les artistes et leurs publics ${ }^{2}$. En considérant le mouvement étudiant comme lieu de recherche créatrice, l'auteure expose les méthodes et activités qui ont aidé à créer des situations et qui ont permis aux visiteurs de participer ou de répondre à la production artistique en cours pendant l'événement Recto/Verso. Dans un environnement en constante évolution, l'auteure aborde le travail de documentation de l'atelier-laboratoire

1 L'École de la Montagne rouge est une initiative de jeunes artistes consciencieux issus du programme de baccalauréat en design graphique de l'Université du Québec à Montréal (UQAM).

2 O'NEIL, Paul et WILSON, Mick (dir.). Curating and the Educational Turn. Londres: Open Editions / Amsterdam: de Appel, 2010; BISHOP, Claire. "The Social Turn: Collaboration and its Discontents ". Artforum, vol. 44, no 6, 2005, p. 178; COESSENS, Kathleen, CRISPIN, Darla et DOUGLAS, Anne. The Artistic Turn: A Manifesto. Belgique: Orpheus Instituut / Louvain: Leuven University Press, 2009; KESTER, Grant. Conversational Pieces: Community and Communication in Modern Art. Berkeley: University of California Press, 2004 
et ses activités parallèles qui ont été diffusées sur un site web Tumblr et ensuite publiées sous forme de petites brochures produites par la Galerie FOFA en novembre 2012. Ces différents types d'interprétations et de modes de diffusion ouvrent d'autres possibilités de production et de dialogues avec le public.

Le collectif Recto/Verso s'est réorienté et a adapté sa programmation éducative pour correspondre aux installations, aux activités et aux événements des artistes participants ainsi qu'au mouvement social lui-même. Recto/Verso: Manifestation/Démonstration a également incarné des pratiques de conservation qui sont à la croisée de l'art, de la politique, de la pédagogie et de l'engagement social. En explorant le rôle de l'artiste comme producteur culturel, cet article fait le lien entre les pratiques créatrices qui ont pris place dans la galerie et celles qui ont eu lieu dans les rues de Montréal au cours des manifestations. Par le biais des multiples activités programmées, la production artistique de cet atelier d'été intensif reprenait les positions, les inquiétudes, les idées et les idéaux du mouvement étudiant, inscrit dans une campagne historique déterminante visant l'accès à l'éducation et la libre expression créatrice ${ }^{3}$. 